(which is usually in the right iliac fossa).

The point is not entirely academic or historical in its importance but has a truly practical application even today. The authority of your editorials is such that young surgeons and others reading your statement of "Murphy's triad" may be persuaded that the diagnosis of acute appendicitis can never be established or accepted when the patient has a normal temperature. They will then refrain from operating when operation without delay may indeed be very necessary. - I am, etc.,

ROBERT S. LaWSON

Melbourne, Australia 1 Murphy, J. B., American Fournal of the Medical

\section{Isoprenaline plus Phenylephrine in Chronic Obstructive Lung Disease}

SiR,-Dr. L. H. Harris's results (5 December, p. 579) add considerably to the evidence already favouring the use of combined isoprenaline-phenylephrine preparations in relieving chronic obstructive lung disease. ${ }^{2}$ In contrast, the inhalation of isoprenaline alone causes a number of unwanted cardiovascular effects. Besides the risk of hypoxaemia patients may experience ventricular irritability, and eventually arrhythmia. The "sudden and unexpected" deaths in asthma have been attributed to one or more of these cardiovascular effects. ${ }^{34}$

I have carried out a double-blind study on ten normal human subjects, using four aerosol preparations; isoprenaline, phenylephrine, the two together (MedihalerDuo), and an inert placebo. Blood pressure and heart rate were measured before and after the four treatments. The mean results are given in the Table.

Phenylephrine administered simultaneously with isoprenaline appreciably reduces the effect on blood pressure and heart rate of isoprenaline alone. These results are compatible with those of Unger et al. obtained in a study on asthmatics. ${ }^{1}$ As far as the present results can be extrapolated to the diseased state, the use of an alpha-receptor stimulant appears to reduce the unwanted and potentially dangerous effects of isoprenaline inhalation.

Department of Physiology,

Neville A. MaRsh Queen Elizabeth College,

London $W .8$

1 Unger, D. L., Temple, D. E., and Unger, L., Fournal of Allergy, 1968, 41, 285. Cohen, B. M., Journal of the American Geri-

Chapman, T. T., and Hughes, D. T., British Spedical Fournal, 1967, 2, 639.

Medical E., Doll, R., and Heaf, P., British

\section{Tumours of the Bladder}

SIR,-The article by Mr. J. Cosbie Ross on management of bladder carcinoma (12 December, p. 661) is an object lesson in how to handle a difficult subject. His criticism of partial cystectomy is timely, and those of us who have had to deal with abdominal wall implants can support his contention that recovery from this is virtually unknown.

It is refreshing that a surgeon of $\mathrm{Mr}$. Ross's stature should pay due tribute to the success of megavoltage therapy in infiltrating tumours of the bladder. Many surgeons will undoubtedly be surprised to learn that post megavoltage cystectomy, although technically difficult, is the most favourable cystectomy from the survival aspect. Surgeons are sometimes disheartened by initial technical failure, but with experience success is the rule. An excellent case can be made out for the referral of post megavoltage recurrences to a specialized unit, and in the Liverpool region this appears to be occurring.

Late complications following megavoltage therapy, such as intractable bleeding and contracted bladder, are becoming less common since the antibacterial agent noxytiolin became part of the planned management. On the first three days of treatment this agent is instilled into the bladder and left in the viscus for at least one hour. Noxytiolin is also useful in inducing haemostatis when bleeding occurs as a late comolication of megavoltage therapy. In tumours recurrent after radiotherapy I would not advise thiotepa, in view of the considerable risk of massive mucosal necrosis with secondary infection and intractable pain.-I am, etc.,

Liverpool Regional Radiotherapy Centre,

M. J. GARRETT

Clatterbridge Hospital West,

irral, Ches

Garrett, M. J., British fournal of Clinical Practice,
1969, 23, 407.

\section{Trachoma in Britain}

SIR,-Over seven years ago you published a letter of mine (25 May, 1963, p. 1412) which suggested there might be a risk of trachoma appearing in this country through the medium of immigration. I suggested that this contagious eye disease should be notifiable. You were good enough following a confirmatory letter (22 June 1963, p. 1673) by $\mathrm{Mr}$. Lionel $\mathrm{M}$. Green, ophthalmologist to one of the large dock hospitals in the East End of London, to print an editorial in which you quoted the opinion of the World Health Organization on this matter (22 June 1963, p. 1626). The latter sug gested that immigrants, if trachoma was still in the state of evolution (that is, usually in a young man or middle-aged person) should be given effective treatment. This is impossible, of course, without notification as I suggested. You also pointed out that it would be difficult to assess whether trachoma constitutes an appreciable risk to public health unless the disease was made notifiable.

I am unaware of any action having been taken by either Government in this matter. My own assessment was that during the next five years there might be a few cases cropping up among children or adults. and that in the next five years small endemic sources might occur despite the high level of hygiene in the greater part of this island. In the light of the recent discovery of the presence of this disease in an active form reported in the newspapers as affecting thirteen British members of the staff at a 5-star, golfing hotel, may I be allowed to ask the Department of Health "what happens now?"-I am, etc.,

Princess Margaret Hospital,

F. C. RODGER

Swindon, Wilts.

\section{Clonidine in Treatment of Hypertension}

SIR,-The paper by Dr. A. Amery, and others (14 November, p. 392) on the treatment of hypertension with clonidine raises several pertinent questions as to its use in hypotensive therapy.

They have compared a centrally acting inhibitor of sympathetic activity, clonidine, ${ }^{1}$ with a peripheral adrenergic-blocking drug, methyldopa, and achieved good results with both, although patients taking clonidine developed a greater incidence of undesirable side effects. The efficacy of methyldopa and a diuretic in the treatment of hypertension seems to be well established, and it is unlikely to be superseded by a drug having a greater incidence of side effects. Therefore the value of clinical trials would seem to be to evaluate whether a third drug, like clonidine, provides an additional advantage when used together with methyldopa and a diuretic.

We have treated 108 hypertensive patients with clonidine, in various combinatiuns, over a period of two years. Thirtyfive patients were treated with clonidine alone, 52 patients were treated with clonidine and a diuretic, and 54 patients were treated with clonidine, methyldopa,

\begin{tabular}{|c|c|c|c|c|c|c|c|c|c|c|c|c|}
\hline & \multicolumn{3}{|c|}{ Placebo } & \multicolumn{3}{|c|}{$\begin{array}{c}\text { Phenylephrine } \\
(240 \mu \mathrm{g})\end{array}$} & \multicolumn{3}{|c|}{$\begin{array}{l}\text { Isoprenaline } \\
(160 \mu \mathrm{g})\end{array}$} & \multicolumn{3}{|c|}{$\begin{array}{l}\text { Isoprenaline, } 160 \mu \mathrm{g} \\
\text { and Phenylephrine } 240 \mu \mathrm{g}\end{array}$} \\
\hline & Before & After & Change & Before & After & Change & Before & After & Change & Before & After & Change \\
\hline $\begin{array}{l}\text { Heart rate } \\
\text { Beats/min. }\end{array}$ & $79 \cdot 7$ & $76 \cdot 0$ & $-3 \cdot 7$ & $78 \cdot 6$ & $78 \cdot 2$ & -0.4 & $77 \cdot 3$ & 94.9 & $+17 \cdot 6$ & $78 \cdot 1$ & $81 \cdot 5$ & +3.4 \\
\hline $\begin{array}{cc}\begin{array}{c}\text { Blood Pressure } \\
\mathrm{mm} / \mathrm{Hg}\end{array} \\
\end{array}$ & $105 \cdot 3 / 67 \cdot 3$ & $101 \cdot 9 / 66 \cdot 4$ & $-3.4 /-0.9$ & $102 \cdot 2 / 67 \cdot 2$ & $103 \cdot 9 / 68 \cdot 0$ & $+1 \cdot 7 /+0 \cdot 8$ & $103 \cdot 2 / 68 \cdot 1$ & $112 \cdot 6 / 55 \cdot 5$ & $+9 \cdot 4 /-12 \cdot 6$ & $104 \cdot 4 / 68 \cdot 5$ & $108 \cdot 4 / 61 \cdot 1$ & $+4 \cdot 0 /-7 \cdot 4$ \\
\hline $\begin{array}{c}\text { Pulse Pressure } \\
\mathbf{m m} / \mathbf{H g}\end{array}$ & $38 \cdot 0$ & $35 \cdot 5$ & -2.5 & $35 \cdot 0$ & 35.9 & +0.9 & $35 \cdot 1$ & $57 \cdot 1$ & $+22 \cdot 0$ & $35 \cdot 9$ & $47 \cdot 3$ & $+11 \cdot 4$ \\
\hline
\end{tabular}

Results from ten subjects. Mean values before drug administration, taken from four steady state readings; mean values after drug, taken from the greatest change 